\title{
Evaluation of Pulasan (Nephelium ramboutan-ake) Genetic Diversity in Bogor, West Java, Using Microsatellite Markers
}

Amelia Luisyane Puhili, Tatik Chikmawati*, Nina Ratna Djuita

\begin{abstract}
Department of Biology, Faculty of Mathematics and Natural Sciences, Bogor Agricultural University, Bogor, Indonesia
\end{abstract}
\section{ABSTRACT}

Pulasan (Nephelium ramboutan-ake (Labill.) Leenh) fruit is highly similar to rambutan rapiah (Nephelium lappaceum) fruit with ovate shape, sweet and sour fresh taste, but it has a thick rind. The diversity of pulasan is little informed including in Bogor. The objective of this study was to analyze the genetic diversity of pulasan from Bogor revealed by microsatellite marker. The DNA of 63 individuals from 10 populations of pulasan were extracted using CTAB method and amplified using two primer sets, LMLY6 (GA)9(CA)2(GA)4 dan LMLY12 (CT)11. DNA amplification product was visualized and arranged in a matrix of binary data then analyzed the value of the number of different alleles $(\mathrm{Na})$, the number of effective alleles $(\mathrm{Ne})$, Shannon information index (I), heterozygosity (He), and the percentage of polymorphism (PLP). The results of the analysis showed the highest genetic diversity was found in North Bogor $(\mathrm{He}=0.313)$. The genetic diversity within a population $(61 \%)$ was higher than that among populations (39\%). A dendrogram was constructed using the Unweighted Pair Group Method with arithmetic Mean (UPGMA). The similarity index ranged from 52 to $100 \%$ that means there are close relationships among individuals. Cluster analyses grouped some individuals originated from different locations in the same group. The levels of heterozygosity within a population was determined by the history of each individual in a population.

Keywords: Bogor, genetic diversity, Nephelium ramboutan-ake, microsatellite

\section{INTRODUCTION}

In Java, pulasan is known as rambutan babat, rambutan ake, and rambutan leci. The plant has leaves and branches that similar to those of rambutan, but it has a smaller size. pulasan fruit is like rambutan, ovate shape with a sweet taste and a slightly sour, but it has a thick rind and with no hairs. Pulasan has many uses. It has quite a hard stem, so it is often used for making household appliances. The seeds contain vegetable oils that can be used to make candles and soaps [1]. In addition, the seeds can be eaten after baked, and the taste likes beans. The baked seeds can be made into a powder and used it like cocoa powder. Pulasan fruit can be eaten directly like rambutan or as an additional ingredient in ice cream, pudding, jam, syrup and mixed in drinks such as cocktails [2].

Pulasan is a native species of Java, Borneo, and the

\section{*Corresponding author:}

Tatik Chikmawati

Department of Biology, Faculty of Mathematics and Natural Sciences, Bogor Agricultural University

Jalan Raya Darmaga, Bogor 16680, Indonesia

E-mail: tchikmawati@yahoo.com
Philippines [3]. Unfortunately, it is now hard to find in Java Island since people's interest to grow pulasan tree decreases due to its low production. Pulasan given its many benefits, and has huge potential for its development as an alternative fruit in the future, however, its diversity in Java island, especially in Bogor, has not been identified. Therefore, it is important to evaluate its genetic diversity.

Microsatellite marker can be used to describe the genetic diversity of pulasan. This marker is often used to describe the diversity of organisms at the species level because its existence is abundant, it produces high polymorphisms, and co-dominant marker [4]. Microsatellite markers had been successfully used to describe the genetic diversity at the species level, for example in rice [5], sorghum [6], and apple [7]. This study aimed to analyze the genetic diversity of pulasan

\section{How to cite:}

Puhili AL, Chikmawati T, Djuita NR (2016) Evaluation of pulasan (Nephelium ramboutan-ake) Genetic Diversity in Bogor, West Java, Using Microsatellite Markers. J. Trop. Life. Science 6 (3): $184-189$. 
Table 1. List of microsatellite primer name and sequences used in the study

\begin{tabular}{lll}
\hline \multicolumn{1}{c}{ Primer } & \multicolumn{1}{c}{ Forward } & \multicolumn{1}{c}{ Reverse } \\
\hline LMLY6 & AAGGAATAAAGCTATCAATAAA & GATCTCTATCTCATCAAACCT \\
LMLY12 & GAAGCTGTCTTAACACTCCAC & ACAAACCTAGAAACCAAAAG \\
\hline
\end{tabular}

in Bogor, West Java, using microsatellite markers.

\section{MATERIALS AND METHODS \\ Sampling}

pulasan leaves were taken from four districts in Bogor Municipality (West Bogor Barat, North Bogor, South Bogor and Central Bogor) and six districts in Bogor Regency (Cileungsi, Sukaraja, Babakan Madang, Ciomas, Parung, and Cibinong). Total samples of the plant taken are 63 trees. From each tree, as many as four to five mature leaves were taken. The leaves were put into plastic bags, added with silica gel, covered, and stored in $\mathrm{a}-20^{\circ} \mathrm{C}$ temperature.

\section{DNA isolation, Polymerase Chain Reaction (PCR) and visualization of PCR results}

Isolation of DNA used the CTAB method [8] with some modifications. PCR amplification method was based on the method conducted by Sim et al. [9] using two pairs of primers, namely LMLY 6 and LMLY 12 (Table 1).

Amplification process was carried out in $25 \mu \mathrm{L}$ mix solution contained $12.5 \mu \mathrm{L}$ of Go Taq Green master mix, $1 \mu \mathrm{L}$ each of primer forward and reverse, $0.25 \mu \mathrm{L}$ BSA, $2 \mu \mathrm{L}$ of DNA, and $8.25 \mu \mathrm{L} \mathrm{ddH}_{2} \mathrm{O}$. This process was performed for 35 cycles consisting of several stages: initial denaturation at a temperature of $94^{\circ} \mathrm{C}$ for 35 seconds, denaturation at $94^{\circ} \mathrm{C}$ for minute, annealing at $46^{\circ} \mathrm{C}$ for the LMLY6 primer and $46.3^{\circ} \mathrm{C}$ for LMLY12 for 35 seconds, and elongation at a temperature of $72^{\circ} \mathrm{C}$ for 10 minutes. Amplification results were then examined using horizontal electrophoresis and used $2.5 \%$ of agarose gel for 100 minutes. Results of electrophoresis were visualized using UV light and then photographed.

\section{Data analysis}

The resulted visualization of PCR was observed by looking at the presence or absence of band considered microsatellite alleles on pulasan accession. When there was a band, then a score of one was given, and when there was none, a score of zero was given. The resulted scores were arranged in a matrix of binary data and then analyzed using the software GenAlex to generate the value of the number of different alleles $(\mathrm{Na})$, the number of effective alleles $(\mathrm{Ne})$, Shannon information index (I), heterozygosity (He), the percentage of polymorphism (PLP) and the analysis of molecular variation (AMOVA). The sample from the Parung District was not analyzed because only one sample was found. Polymorphism percentage value is calculated with the following formula:

$$
\begin{gathered}
N_{e}=\frac{1}{p^{2}+q^{2}} \\
I=-(p \times \operatorname{Ln}(p)+q \times \operatorname{Ln}(q)) \\
H_{e}=2 \times p \times q
\end{gathered}
$$

With the $q=\sqrt{\text { frequency of band absence }}$ and $\mathrm{p}=1-\mathrm{q}$ according to Hardy-Weinberg equilibrium [9]. The dendrogram was constructed using the Jaccard coefficient and Unweighted Pair Group Method with Arithmatic Mean (UPGMA), it performed using the software NTSYS-pc ver 2.1 [10].

\section{RESULTS AND DISCUSSION Pulasan exploration}

Based on the resulted exploration in Bogor Regency and Municipality, the study found pulasan plants in ten districts (Table 2). pulasan trees found on all locations are 63 trees in number. The district with the highest number of trees is Cileungsi with as many as 13. The district with the least number of trees is Parung. The number of locations where pulasan trees found varies with each district.

\section{Pulasan DNA amplification}

All pulasan plants of Bogor have successfully been amplified using LMLY6 and LMLY12. LMLY6 Primer generated PCR products in the form of two DNA bands of $140 \mathrm{bp}$ and $160 \mathrm{bp}$ (Figure 1). The bands with the size of $160 \mathrm{bp}$ were amplified in all plants, while the size of 140 bp only amplified in some plants. Thus, the $140 \mathrm{bp}$ band shows variations in LMLY6 primer. Unlike LMLY6 primer, LMLY12 produced PCR products with 2 - 7 DNA bands per individual pulasan (Figure 2). The band sizes generated by LMLY12 were of 150 bp, 200 bp, 225 bp, 250 bp, 400 bp, 450 bp and $500 \mathrm{bp}$. Among the resulted PCR of LMLY12, two bands tend to be amplified in each plant, namely the sizes of $225 \mathrm{bp}$ and $450 \mathrm{bp}$. While the other bands produced using LMLY12, show variation among indi- 


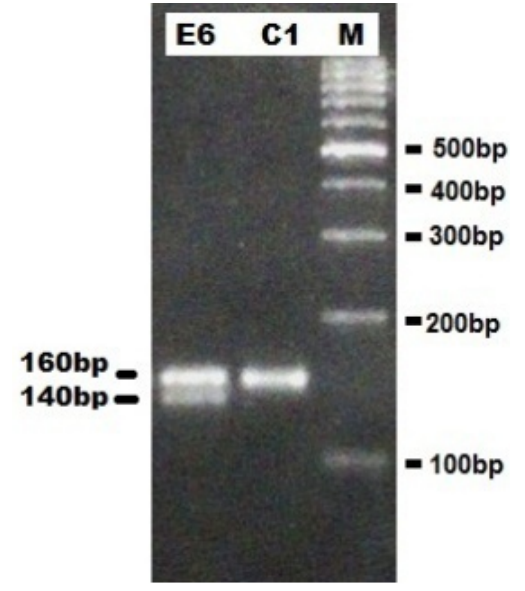

Figure 1. DNA amplification of pulasan genome in several districts in Bogor using LMLY6 primer and an annealing temperature of $46.3^{\circ} \mathrm{C}$ on agarose gel of $2.5 \%$. (M: DNA Marker 1000 bp; E: North Bogor; C: Ciomas.)

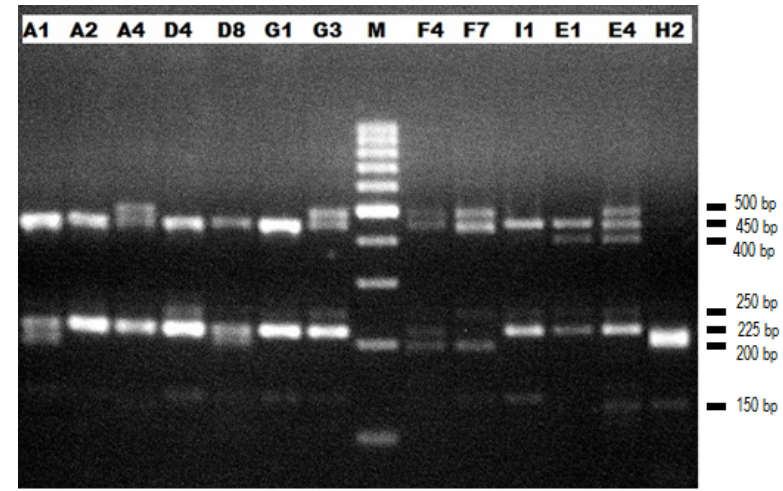

Figure 2. Variations in DNA amplification results of pulasan genome in several districts in Bogor using LMLY12 primer and an annealing temperature of $46^{\circ} \mathrm{C}$ on agarose gel of 2.5\%. (M: DNA Marker 1000 bp; A: Cileungsi; D: Sukaraja; E: North Bogor; F: Babakan Madang; G: West Bogor; H: Central Bogor. I: Cibinong)

vidual pulasan tree. Thus, the higher level of polymorphism is generated by the LMLY12 primer.

\section{Genetic diversity of pulasan}

The analysis of genetic diversity on two microsatellite primers showed that pulasan in the District of North Bogor has the highest values of heterozygosity $(\mathrm{He}=0313)$, Shannon information index $(\mathrm{I}=0458)$, and percentage of polymorphism (77.78\%) (Table 3). The lowest values of heterozygosity, Shannon information index and the percentage of polymorphism were found in Ciomas District. Cileungsi District is the district with the highest number of pulasan trees (13 trees). However, the genetic diversity value in the District is low $(\mathrm{He}=0102, \mathrm{I}=0175$, and PLP $=55.56)$. This value is lower than those of heterozygosity and polymorphism percentage in North Bogor District where only six trees are found. pulasan in Babakan Madang District is also the same as that of Cileungsi District, with a large population size but it has low genetic diversity. In contrast to those locations, pulasan found in Central Bogor and Cibinong districts are less than five trees, but they have high values of heterozygosity and polymorphism. pulasan is also found less than five trees in Ciomas, but the values of heterozygosity $(\mathrm{He}=0.026)$ and polymorphism percentage (11 : $11 \%)$ of pulasan in Ciomas District are lower than those of Central Bogor District and Cibinong.

The average percentage of polymorphism of Bogor pulasan is $44.44 \%$. A locus is categorized as polymorphic if the frequency of an allele is $<99 \%$ [11]. Thus, all loci generated by Bogor pulasan is polymorph. Evaluation of the genetic diversity using microsatellite markers on annual plant been made. An observation of genetic diversity of apples coming from the Swiss Federal Research Staton, Switzerland and Philip Forsline at The National germplasm repository for Apple and Grape, USA, showed that the average of heterozygosity value was 0.78 , which is categorized as very high [7]. In contrast to the observation on apples, the genetic diversity of woody plants in tropical forests was lower, $\mathrm{He}=0.149$ [12]. Comparing to the previous studies, the average value of pulasan heterozygosity is quite high, $\mathrm{He}=0.161$.

The higher the value of heterozygosity in a population, the higher the genetic variation in the population [13]. Pulasan population in North Bogor District has the highest genetic variation, whereas that of Ciomas District has the lowest genetic variation. According to Nei [14], one of the factors affecting the level of heterozygosity is the population size. The population in North Bogor District is classified low $(\mathrm{N}=6)$. However, Cileungsi District with the largest population size $(\mathrm{N}=13)$ also has a quite low value of heterozygosity. In contrast to both districts, a small population of Cibinong District $(\mathrm{N}=2)$ showed a high heterozygosity, $\mathrm{He}=0.230$. The low heterozygosity of pulasan in Cileungsi district may occur because all samples were originated from the same location, Taman Buah Mekar Sari. All pulasan trees in this place were propagated by grafting from the experimental garden in Cipaku. Thus, all individuals are genetically alike. Whereas, $p u^{-}$ lasan individuals in the Districts of North Bogor and Cibinong pulasan came from different locations. Thus, 
Table 2. Exploration locations and the number of trees found

\begin{tabular}{lll}
\hline \multicolumn{1}{c}{ Districts } & \multicolumn{1}{c}{ Location } & Number of trees \\
\hline West Bogor & Cibalagung & 3 \\
& Gunung Batu & 1 \\
South Bogor & Curug Mekar & 1 \\
Center Bogor & Cipaku field trial & 9 \\
& Panaragan & 1 \\
North Bogor & Bogor Botanical Garden (KRB) & 3 \\
& Cimahpar & 2 \\
Babakan Madang & Makam Bodas & 4 \\
Cibinong & Cijayanti & 11 \\
& Sukahati & 1 \\
Cileungsi & Nanggewer & 1 \\
Ciomas & Taman Buah Mekar Sari & 13 \\
Parung & Kota Batu & 4 \\
Sukaraja & Jabon Mekar & 1 \\
Total & Cikeas & 8 \\
\hline
\end{tabular}

Table 3. Genetic Diversity of pulasan in ten districts in Bogor

\begin{tabular}{lllllll}
\hline Populations & $N$ & $N a$ & $N e$ & $I$ & $H e$ & $P L P$ \\
\hline West Bogor & 5 & 1.444 & 1.387 & 0.319 & 0.218 & $55.56 \%$ \\
South Bogor & 9 & 0.889 & 1.118 & 0.111 & 0.073 & $22.22 \%$ \\
Center Bogor & 4 & 1.222 & 1.368 & 0.309 & 0.209 & $55.56 \%$ \\
North Bogor & 6 & 1.778 & 1.541 & 0.458 & 0.313 & $77.78 \%$ \\
Babakan Mandang & 11 & 1.333 & 1.334 & 0.260 & 0.180 & $44.44 \%$ \\
Cibinong & 2 & 1.556 & 1.393 & 0.336 & 0.230 & $55.56 \%$ \\
Cileungsi & 13 & 1.333 & 1.142 & 0.175 & 0.102 & $55.56 \%$ \\
Ciomas & 4 & 0.778 & 1.034 & 0.044 & 0.026 & $11.11 \%$ \\
Sukaraja & 8 & 0.778 & 1.179 & 0.141 & 0.099 & $22.22 \%$ \\
\hline Average & 6.889 & 1.235 & 1.277 & 0.239 & 0.161 & $44.44 \%$ \\
\hline
\end{tabular}

Note: $\quad \mathrm{N}$ = number of samples; $\mathrm{Na}=$ number of different alleles; $\mathrm{Ne}=$ number of effective alleles; $\mathrm{I}=$ index of Shannon information; $\mathrm{He}=$ heterozygosity; PLP = percentage of polymorphisms

Table 4. Analysis of molecular variation (AMOVA) of pulasan populations

\begin{tabular}{llllll}
\hline & df & SS & MS & Est. Var. & $\%$ \\
\hline Among populations & 8 & 33.256 & 4.157 & 0.503 & $39 \%$ \\
Within populations & 53 & 42.486 & 0.802 & 0.802 & $61 \%$ \\
\hline Total & 61 & 75.742 & & 1.304 & $100 \%$ \\
\hline
\end{tabular}

Note: $\mathrm{df}=$ degrees of freedom; $\mathrm{SS}=$ sum of squares; $\mathrm{MS}=$ middle square

in addition to the population size, two other possibilities are affecting the genetic diversity level of pulasan, the origin of the individuals making up the population and the multiplication through vegetative reproduction. According to the previous study, other factors may affect the value of heterozygosity within a population, such as mutation, reproductive and recombinant traits, random mating, and natural selection [15].

AMOVA results show that the variation in the population $(61 \%)$ is higher than the variation between populations (39\%) (Table 3). Variations in large populations can occur as a result of interbreeding (Hamrick 


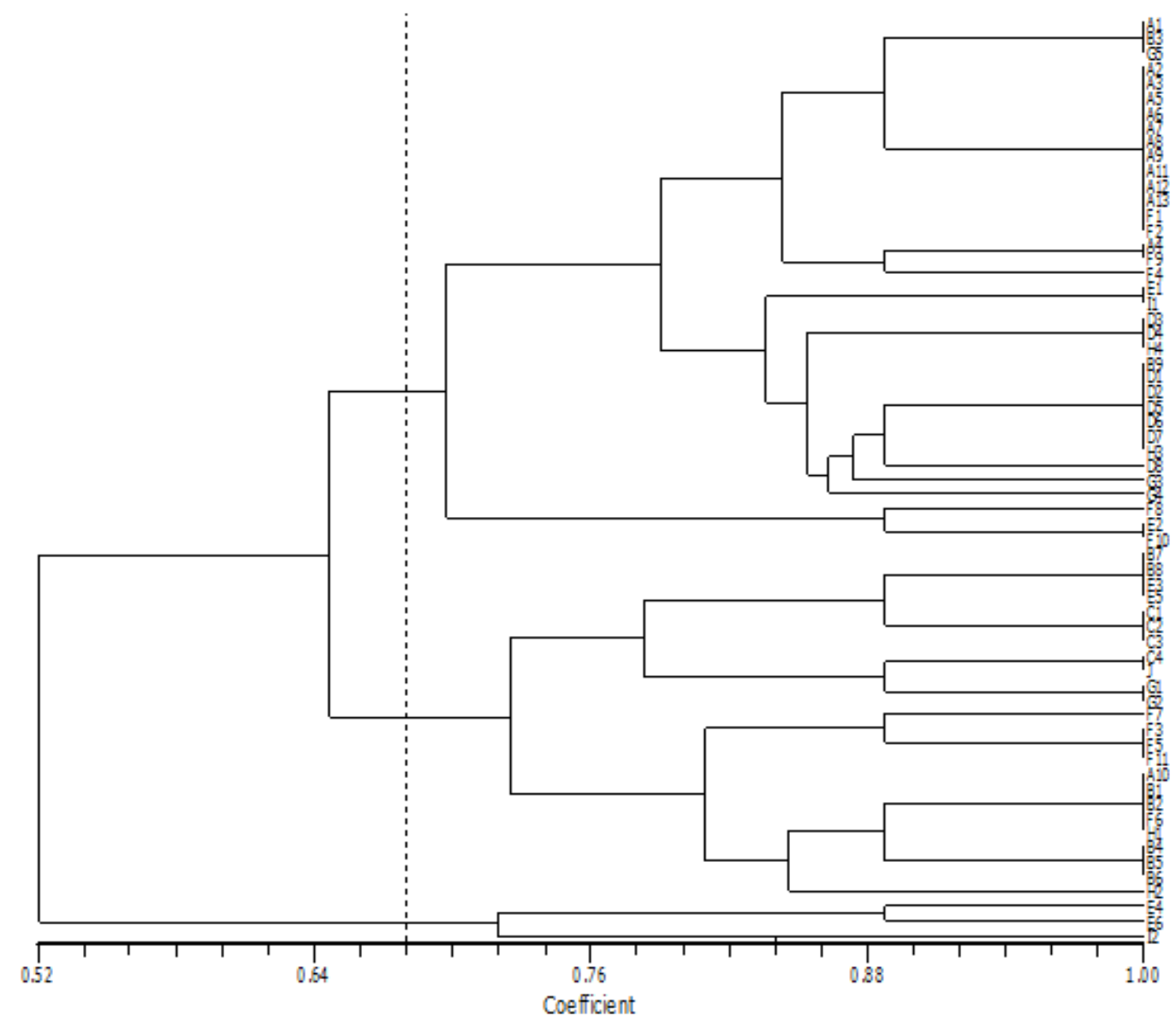

Figure 3. Dendrogram of pulasan in Bogor constructed by the Jaccard coefficient and UPGMA method based on microsatellite data. A1-13: Cileungsi; B1-9: South Bogor; C1-4: Ciomas; D1-8: Sukaraja; E1-6: North Bogor; F1-11: Babakan Madang; G1-6: West Bogor; H1-4: Center Bogor; I1-2: Cibinong; J1: Parung.

1989). In addition, a broader distribution of plants, a large size, and an adjacent location of populations will produce considerable variation in the population because it will facilitate the occurrence of gene flow [16].

\section{Pulasan relationship}

The degree of similarity in the 63 samples of $\mathrm{pu}$ lasan varies from 0.52 to 1.00 . In the similarity level of $68 \%$, all of the samples split and form into three main groups. The first group is pulasan of the Districts: Cibinong, Babakan Madang, Ciomas, and North Bogor. The second group is pulasan of the Districts: Ciomas, South Bogor, North Bogor, Parung, West Bogor, Babakan Madang, Cileungsi, and Central Bogor. The third group is pulasan of the Districts: Cileungsi, Babakan Madang, North Bogor, West Bogor, South Bogor, Cibinong, Sukaraja, and Central Bogor.

The results of cluster analysis (Figure 3) shows that individual pulasan do not cluster based on the origin of the population but they are scattered randomly, except for the population of Sukaraja District. pulasan from this district is identical, with the similarity level of $100 \%$. The same individual trees occur since all pulasan of Sukaraja comes from trees grafted from the oldest tree in the area. pulasan B3 from the Experimental Garden of Cipaku is grouped together with pulasan of Cileungsi District, indicating that it is the progenitor of pulasan in Taman Buah Mekar Sari, Cileungsi.

Pulasan Individual from Bogor Botanical Gardens (KRB) and Cibinong District are grouped into populations from different locations. This result can be explained since $\mathrm{KRB}$ is a garden of plant collection that gathers all plants from different places. Pulasan individuals of Cibinong is also found from various and distant locations.

\section{CONCLUSION}

As many as 63 pulasan trees were found in ten Districts and Municipality of Bogor. All pulasan trees have been successfully amplified using the primers LMLY6 
and LMLY12 with the annealing temperature of $46.3^{\circ} \mathrm{C}$ and $46^{\circ} \mathrm{C}$ respectively. Primer LMLY6 produces two bands of $140 \mathrm{bp}$ and $160 \mathrm{bp}$, while, Primer LMLY12 produced seven sizes of DNA bands, $150 \mathrm{bp}, 200 \mathrm{bp}$, 225 bp, 250 bp, 400 bp, 450 bp and 500 bp. The highest genetic variation of pulasan population is found in North Bogor $(\mathrm{He}=0.313)$. The percentage of variation within a population $(61 \%)$ is higher than between populations, $39 \%$. The level of genetic similarity between pulasan trees ranged $52-100 \%$, which means that the relationship among pulasan individuals is quite close. The origins of the individuals that make up the population determine the level of the population heterozygosity.

\section{ACKNOWLEDGMENT}

We gratefully acknowledge Indonesian Directorate General of Higher Education (DIKTI) for providing financial support through the research project of Penelitian Unggulan Perguruan Tinggi, on behalf of Dr. Tatik Chikmawati, M.Si. in 2014-2015.

\section{REFERENCES}

1. [BK-Kehati] Balai Kliring Keanekaragaman Hayati Indonesia (2013) Tenggaring. [Internet]. [diunduh pada 24 November 2013]. Tersedia pada: http://www.bk.menlh.go.id/.

2. Lim TK (2013) Edible Medicinal and Non Medicinal Plants: Volume 6, Fruits. Canberra (AU): Springer Netherlands.

3. Leenhouts P W (1986) A taxonomic revision of Nephelium (Sapindaceae). Blumea 31, 373-436.

4. McCouch SR, Teytelman L, Xu Y et al. (2002) Development and mapping of 2240 new SSR markers for rice (Oryza sativa L.) DNA Res. 9:199-207.
5. Brondani C, Hideo P, Rangel N, Borba TCO, Brondani RPV (2003) Transferability of microsatellite and ISSR markers in Oryza species. Hereditas 138:187-192.

6. Gianfranceschi L, Seglias N, Tarchini R, Komjanc M, Gessler C (1998) Simple sequence repeats for the genetic analysis of apple. Theor Appl Genet. 96: 1069-1076.

7. Doyle JJ, Doyle JL (1990) Isolation of plant DNA from fresh tissue. Focus.12: 13-15.

8. Sim CC, Mahani MC, Choong YC, Salma I (2005) Transferability of SSR markers from lychee (Litchi chinensis Sonn.) to pulasan (Nephelium ramboutan-ake L.) Fruits. 60:379-384.

9. Peakall R, Smouse PE (2012) GenAlEx 6.5: genetic analysis in Excel. Population genetic software for teaching and research. Bioinformatics 28: 2537-2539.

10. Rohlf FJ (2000) NTSYS pc Numerical Taxonomy and Multivariate Analysis System Version 2.1. New York (US): Applied Biostatistic Inc.

11. Li WH, Graur D (1991) Fundamentals of Molecular Evolution. Massachusetts (US): Sinaur Associates Inc.

12. Hamrick JL, Godt MJW, and Sherman-Broyles SL (1992) Factors influencing levels of genetic diversity in woody plantspecies. New For. 6: 95-124.

13. Ferguson A (1980) Biochemical Systematics and Evolution. London (GB): The Queens University of Belfast.

14. Nei M (1987) Molecular Evolutionary Genetics. New York (US): Columbia Press.

15. Pai AC (1992) Dasar-Dasar Genetika. Jakarta (ID): Penerbit Erlangga.

16. Hartati D, Rimbawanto A, Taryono, Sulistyaningsih E, Widyatmoko AYPBC (2007) Pendugaan keragaman genetik di dalam dan antar provenan pulai (Alstonia scholaris (L) R. Br.) menggunakan penanda RAPD. Jurnal Pemuliaan Tanaman Hutan 2: 98-98. 